\title{
EFFECT OF GCG AND FINANCIAL PERFORMANCE ON THE QUALITY OF INTERNET FINANCIAL REPORTING
}

\author{
Putri Dwi Wahyuni*), Febrina Mahliza \\ University of Mercu Buana \\ putri.dwi@mercubuana.ac.id
}

\begin{abstract}
This study aims to analyze and measure the effect of the mechanism of Good Corporate Governance and Financial Performance on the quality of Internet Financial Reporting. This research was conducted in the manufacturing sector on the IDX during the 20152016 period. Based on the method of sample selection, the sample was obtained at the end of a study of 140 data with 70 issuers being 125 data from the manufacturing sector on the IDX. The analytical method used is multiple regression analysis. The t-test statistic was carried out before multiple regression equation analysis, in the first stage the classical assumption was tested which consisted of normality, multicollinearity, heteroscedasticity, and autocorrelation. Based on the results of the analysis, it is known that institutional ownership, the proportion of independent commissioners, frequency of meeting of commissioners, return on assets and leverage have no effect on Internet Financial Reporting. The coefficient of determination that sees the influence of the independent variable used in the research model of the dependent variable is $9.30 \%$, while the rest $(90.70 \%)$ is explained by other variables

Keyword: GCG, ROA, Leverage, IFR
\end{abstract}

\section{INTRODUCTION}

In the current era of globalization, technological development is increasingly rapid, especially in the field of information technology such as the internet. This is indicated by the number of users from year to year has always experienced an increase, including Indonesia

Based on data obtained from Internet World Stats (2017). Asia ranks top in internet usage in the world with a percentage of $49.88 \%$. In Indonesia, the number of internet users as of 30 June 2017 was $6.8 \%$ at the first place. Then followed by Vietnam at $3.3 \%$ and Philippines at 3\%

Table 1. Internet users in Asia estimated in June 30, 2017

\begin{tabular}{|c|c|c|c|c|}
\hline Southeast ASIA & $\begin{array}{c}\text { Population } \\
\text { (2017 est) }\end{array}$ & $\begin{array}{c}\text { Internet Users } \\
\text { (Year 2000) }\end{array}$ & $\begin{array}{c}\text { Internet Users } \\
\text { (30 June 2017) }\end{array}$ & $\begin{array}{c}\text { Users } \\
\%\end{array}$ \\
\hline
\end{tabular}




\begin{tabular}{|l|r|r|r|c|} 
Indonesia & 263.510 .146 & 2.000 .000 & 132.700 .000 & $6,8 \%$ \\
\hline Vietnam & 95.414 .640 & 200.000 & 64.000 .000 & $3,3 \%$ \\
\hline Philippines & 103.796 .832 & 2.000 .000 & 57.607 .242 & $3,0 \%$ \\
\hline Thailand & 68.297 .547 & 2.300 .000 & 57.000 .000 & $2,9 \%$ \\
\hline Malaysia & 31.164 .177 & 3.700 .000 & 24.554 .255 & $1,3 \%$ \\
\hline Myanmar & 54.836 .483 & 1.000 & 13.747 .506 & $0,7 \%$ \\
\hline Singapore & 5.784 .538 & 1.200 .000 & 4.699 .204 & $0,2 \%$ \\
\hline Kamboja & 16.076 .370 & 6.000 & 4.115 .551 & $0,2 \%$ \\
\hline Laos & 7.037 .521 & 6.000 & 1.539 .106 & $0,1 \%$ \\
\hline Brunei Darussalam & 434.448 & 30.000 & 325.836 & $0,0 \%$ \\
\hline Timor Leste & 1.237 .251 & & 340.000 & $0,0 \%$ \\
\hline \multicolumn{2}{|r|}{ Soure } & & & \\
\hline
\end{tabular}

Source: www.internetworldstats.com (accessed Oct 25, 2017)

In accordance with the regulations of the Financial Services Authority Number 29 / POJK.04 / 2016 concerning the annual report of an issuer or public company chapter IV article 15 paragraph (1) and (2), namely "Annual report must be posted on the Issuer's or Public Company Website on the same date with the submission of the Annual Report to the Financial Services Authority (paragraph 1) ". "The Annual Report contained in the Website as referred to in paragraph (1) must be available within a certain period of time as stipulated in the Financial Services Authority Regulation concerning the Website of the Issuer or Public Company (paragraph 2)".

The existence of these regulations is expected to encourage companies that already have a website to immediately implement IFR. It also encourages companies to be more transparent about information that is important for investors in making decisions. The higher the level of published information disclosure, the greater the influence on investor decisions (Ashbaugh et al., 1999). Using internet financial reporting will make it more efficient both in terms of cost and time. Other than that. the range is also very broad, which can be accessed anywhere and anytime.

In Indonesia, the problem of Corporate Governance has emerged since the economic crisis that hit Asian countries including Indonesia and is increasingly becoming a concern due to the many cases of financial report manipulation. The problem of Corporate Governance began to increase along with the opening of the financial scandals in 2001 that occurred in public companies that involved manipulation of financial statements by PT Lippo Tbk and PT Kimia Farma Tbk (Boediono, 2005). The low level of corporate governance, weak investor relations, lack of transparency, inefficiency in 
financial reports and the lack of law enforcement on legislation in punishing perpetrators and protecting minority shareholders are triggers and the reasons for several companies in Indonesia to collapse (Hardikasari, 2011).

The disclosure of internet financial reporting cannot be separated from the company's financial performance which can be a clue as to what corporate IFR disclosures on their website are in this case the website is not only intended as a marketing medium but also as a medium for connecting companies with investors. The annual report is one of information picturing corporate performance in certain period. This information is provided by the management to the stakeholders. There are two type of information, the quantitative and qualitative. Financial report is quantitative information, mainly profitability and leverage is very interested for investor. (Utami, 2015). Financial performance can be shown in the company's financial statements, especially the company's financial position report which contains past financial information and income statement to assess the company's profit obtained from year to year. While on the other hand there are those who think that the value of the company is not just from the financial statements but the value of the company is assessed based on the present value of the assets owned by the company and the value of the company's investment to be issued in the future (Hidayah, 2015).

Ezat and El-Masry (2008) examined the effect of corporate governance on IFR timeliness. As a result, there is a positive relationship between IFR timeliness with firm size, industrial sector, liquidity, ownership structure, composition of the board of directors and the size of the board of directors. Ghanem and Ariff (2016) stated that the board of directors and audit committee had a significant effect on the level of disclosure of internet financial reporting. Another difference with this study is using good corporate governance mechanism variables (institutional ownership, proportion of independent commissioners, and frequency of commissioner) and financial performance (ROA and leverage). In addition, the object of this study is the manufacturing industry in 2015 to 2016. The formulation of the problem in this study is whether institutional ownership, the proportion of independent commissioners, frequency of commissioner meetings, ROA, leverage affect the quality of internet reporting in partial

\section{LITERATURE REVIEW}

\subsection{Agency Theory}

Jensen and Meckling (1976) define Agency theory as the relationship between agent (management) and Principal (company owner) who are bound in a contractual. Principal assigns agents to provide services for the principal's interests. In agency theory, there is a work contract that regulates the proportion of utility of each party while still taking into account the overall benefit 


\subsection{Signaling Theory}

Signaling theory according to Spence (1973) states that highperformance companies use financial information to send signals to the market. Signaling theory explains how signals of success or failure of management (agent) are conveyed to the owner (principal).

Ettredge et al., (2001) states that IFR helps companies to disseminate information about the company's advantages which is a positive signal of the company to attract investors. This means, IFR is a means to communicate positive signals of the company to the public, especially investors. Companies with high performance tend to use internet financial reporting to help them deliver positive signals (good news) to investors.

\subsection{Internet Financial Reporting (IFR)}

Internet Financial Reporting is a process that companies carry out their financial statements through the internet through a website owned by the company. In this new approach, companies use the internet to market the company to investors and shareholders. Companies that implement internet financial reporting, marketing activities are no longer limited to products only and company websites are not only intended for consumers only (Rahmadiani, 2012)

\subsection{Good Corporate Governance}

Good corporate governance is a mechanism used to ensure that financial suppliers, for example shareholders and lenders (bondholders) companies obtain returns from activities carried out by managers with the funds they have invested or in other words how suppliers of corporate finance exercise control over managers (Shleifer and Vishny, 1997)

\subsection{Financial Performance}

1) Return on Asset

Profitability (return on asset) from the company's operational activities is a ratio that shows how much the asset contribution in creating net income

2) Leverage

Leverage refers to the use of financial funds such as debt and loan funds to increase the return on equity held. High leverage companies have the motivation to provide voluntary disclosure through different communication channels, including internet reporting, to reduce agency costs and information asymmetry (AlArussi et al., 2009; Mendes-daSilvia and Christensen, 2004; Oyelere et al, 2003)

\subsection{Hypothesis}

$\mathrm{H} 1=$ Institutional ownership has a positive effect on the quality of internet financial reporting

$\mathrm{H} 2=$ The frequency of board meeting meetings has a positive effect on the quality of internet financial reporting

$$
\mathrm{H} 3=\begin{gathered}
\text { The proportion of } \\
\text { independent commissioners }
\end{gathered}
$$


has a positive effect on the quality of internet financial reporting

$$
\begin{aligned}
\mathrm{H} 5= & \text { Return on Assets has a } \\
& \text { positive effect on the } \\
& \text { quality of internet financial } \\
& \text { reporting } \\
\mathrm{H} 6= & \text { Leverage has a positive } \\
& \text { effect on the quality of } \\
& \text { internet financial reporting }
\end{aligned}
$$

\section{RESEARCH METHODOLOGY}

\subsection{Data Collection Method}

Data collection techniques used in this study are documentation methods using secondary data from annual reports obtained from the IDX website and research library. The sample in this study are 40 emiten for 2 year (2015-2016). Sampling method with purposive sampling based on the following criteria:

1) Annual report is available both IDX and on the company's website

2) Emiten have a website

3) The currency unit used is rupiah IFR Index $=\frac{\text { Maximum number of }}{\text { Independent Variables }}$

a. Institutional Ownership Institutional ownership is the ownership of a company's shares owned by institutions or institutions such as banking, insurance and investment companies (Tarjo, 2008). Institutional ownership is measured using a comparison between the
4) Emiten do not conduct mergers or acquisitions in the year of research

3.2 Definition of Operational Variables

1) Dependent variable

The dependent variable used in this study is financial internet reporting on manufacturing sector that is listed on the Indonesia Stock Exchange. Disclosure of Internet Financial Reporting (IFR) is measured through the Internet Disclosure Index (IDI) based on OJK No.8 / POJK.04 / 2015 regulations consisting of 63 items namely general information (20 items), information for investors/ investors (25 items), information corporate governance (6 items) and corporate social responsibility information (12 items). Each list item is rated "1" if an IFR timekeeping item is found on the company's website and given a number " 0 " if the IFR timekeeping item is not found on the company's website 
policy and is a medium of communication and coordination among members of the board of commissioners in carrying out their duties as supervisors and as a benchmark of company performance. In this study, the frequency of board commissioner meetings was measured by the number of special meetings of the board of commissioners held for one year (Yatim et al, 2006)

c. Proportion of Independent Commissioners

In the framework of managing corporate governance, listed companies must have independent commissioners whose numbers are proportionally to the number of shares owned by non-controlling shareholders provided that the number of independent commissioners is at least $30 \%$ of the total number of members of the board of commissioners.

The proportion of independent board of directors is measured by dividing the number of independent board of commissioners with the total members of the board of commissioners such as the research conducted by Juniarti and Agnes (2010)

d. Return on Assets

ROA is used to measure the level of efficiency and effectiveness of the company's operational activities in the use of assets owned by the company (Ramananda and Nugrahanti, 2014). ROA in this study is measured by earnings after tax in total assets

e. Leverage

Leverage emphasizes the importance of debt financing for companies by showing the percentage of company assets supported by debt financing (Daniel, 2013). Leverage (financial risk), measured as total debt to total assets

f. Variable Control (Size) Firm size is a big or small picture of a company that can be measured by the value of assets, sales, or from the company's equity market value. Purnomosidhi (2006) that to determine the effect of potential size on the number of disclosures of intellectual capital, an index is measured using natural logarithms of the company's total assets

\subsection{Data Analysis Techniques}

In testing the hypothesis proposed in this study. The researcher uses multiple linear regression analysis methods because of the relationship between two or more independent variables which previously carried out the classical assumption in the first stage 


\section{RESULTS AND DISCUSSION}

\subsection{RESULT \\ 1) Descriptive Statistics}

Tabel 4.1

Descriptive Statistics

\begin{tabular}{|l|c|r|r|r|r|}
\hline & $\mathrm{N}$ & \multicolumn{1}{c|}{ Min } & \multicolumn{1}{c|}{ Max } & \multicolumn{1}{c|}{ Mean } & Std Deviation \\
\hline IFR & 125 & 26.47 & 91.18 & 61.86 & 17.52 \\
INS_OWN & 125 & 20.96 & 99.42 & 68.77 & 18.63 \\
MEETING & 125 & 1 & 13 & 6.14 & 2.77 \\
COMM & 125 & 25.00 & 60.00 & 39.56 & 7.60 \\
ROA & 125 & -1.44 & 27.26 & 7.22 & 6.16 \\
LEV & 125 & 9.77 & 81.97 & 39.29 & 16.71 \\
Size & 125 & 25.62 & 32.15 & 28.40 & 1.49 \\
\hline
\end{tabular}

Table 4.1 shows the results of descriptive statistics after 15 data outliers are removed so that the sample data currently amounts to 125 data which previously amounted to 140 data. Below is a description of the research variables from statistical descriptive results.

The average IFR of 61.86 means that the average quality of the company's internet reporting is $61.86 \%$. This shows that the company's internet reporting level is relatively large, which means that half of the sample under study provides financial and non-financial information to stakeholders on the website. Standard deviation is $17.52 \%$. The average KEP_INST is 68.77 which means that the average institutional ownership is $68.77 \%$. Standard deviation is $19.07 \%$. The average FREK_RAPAT of 6.14 means that the average frequency of board meetings is $6.14 \%$. This shows that the supervision process and evaluation reports on the company's operational activities are very large.
Standard deviation is $2.77 \%$. The average COMM of 39.56 means that the average proportion of the board of commissioners in the economic and business fields is quite large, amounting to $39.56 \%$. This shows that the minimum number of $30 \%$ of the total commissioners required by the OJK has been fulfilled. The standard deviation is $24.17 \%$. The average ROA of 7.22 means that the average rate of return on corporate assets is $7.22 \%$. This shows that the company's ability to own assets is less effective in generating profits. Standard deviation is $6.16 \%$. The average LEV of 39.29 means that the average leverage generated is $39.29 \%$. The higher the leverage of the company, the company will be responsible for satisfying the creditor's information needs by disclosing reliable information through the company's website, making the creditor more confident about the company's ability to pay its debt. Standard deviation is $16.71 \%$ 
2) Classic Assumption Test

In this study, the classical assumption is free, that is the data is normally distributed with the value of Asym. Sig. (2tailed) of $\quad 0.200$. Multicollinearity free by showing that there is no independent variable that has a tolerance value of less than 0.10 which means there is no correlation between independent variables whose values are more than $95 \%$ and the Variance Inflation Factor (VIF) value also shows the same thing. has a VIF value of more than 10 (Ghozali, 2013). Free heteroscedasticity which shows scatterplots graph shows that the points spread randomly and spread both above and below the number 0 on the $\mathrm{Y}$ axis. Autocorrelated free with DW values between -2 to +2 which is 2,172

\section{3) Hypothesis Test}

Table 2 Summary of Hypothesis Test Results

\begin{tabular}{|l|r|r|r|c|}
\hline Variabel Dependen : IFR & \multicolumn{1}{|c|}{} & & \\
\hline Variabel & Coefficient & Std Error & t-Statistic & Prob \\
\hline Constant & $-36,259$ & 30,280 & $-1,197$ & 0,234 \\
\hline INS_OWN & $-0,002$ & 0,081 & $-0,023$ & 0,982 \\
\hline MEETING & 0,051 & 0,567 & 0,091 & 0,928 \\
\hline COMM & $-0,313$ & 0,204 & $-1,536$ & 0,127 \\
\hline ROA & 0,074 & 0,286 & 0,261 & 0,795 \\
\hline LEV & 0,151 & 0,102 & $-1,489$ & 0,139 \\
\hline Size (Control) & 4,074 & 1,091 & 3,734 & 0,000 \\
\hline R-Squared & \multicolumn{5}{|l}{0} \\
\hline Adjusted R-Squared & \multicolumn{5}{|l}{0,137} \\
\hline ANOVA & \multicolumn{5}{|l}{} \\
\hline
\end{tabular}

In table 4.2 shows that the coefficient of determination which shows the adjusted $\mathrm{R}$-square value of 0.093 . This means that $9.30 \%$ of the variation in the number of Internet Financial Reporting (IFR) can be explained significantly by variations in the variables Kep_Inst, Freq Rapat, Prop_Kom, LEV and ROA while $(100 \%-9.3 \%)=90.7 \%$ of the amount of Internet financial reporting can be explained by other variables. The ANOVA sig value shows $0.007<0.05$, so it can be concluded that the variables Kep_Inst, Frek_Rapat, Prop_Kom, LEV and ROA together influence the Internet Financial Reporting and the model is worthy of research 


\subsection{Discussion}

1) Effect of Institutional Ownership on the Quality of Internet Financial Reporting

Institutional ownership has an effect but not significant on internet quality financial reporting as indicated by a regression coefficient of -0.002 and a significance value of 0.982 so that $\mathrm{H} 1$ is rejected. This is because the number of company shares that are owned by an institution that is considered capable in conducting strict supervision for management in the decisionmaking process in fact raises conflicts between institutional investors and management that will make a negative impact on the market so that the quality of internet financial reporting becomes low. This study contradicts what was done by Ezat and El-Mashry (2008), Harsanti, Mulyani and Fahmi (2014) which stated that ownership structure has a positive effect on the quality of internet financial reporting

2) Effect of Frequency of Board of Commissioners Meetings on the Quality Internet Financial Reporting

Frequency of board of directors meetings had an effect but not significant on internet quality financial reporting as indicated by a regression coefficient of 0.051 and a significance value of 0.928 so that $\mathrm{H} 2$ was rejected. The more frequency of meetings held by the board of commissioners should further improve management performance as evidenced by the increasingly high quality of financial reporting. This is in line with research conducted by
(Siagian and Ghozali, 2012) which states that the activities of the board of commissioners do not affect the disclosure of internet financial reporting

3) Effect of the Board of Commissioners' Proportion on the Quality Internet Financial Reporting

Institutional ownership had an effect but not significant on internet quality financial reporting as indicated by a regression coefficient of -0.313 and a significance value of 0.127 so that $\mathrm{H} 3$ was rejected. In this study, the proportion of independent commissioners that are large enough in the company is considered not able to conduct monitoring activities as a representative of internal control mechanisms and control of opportunistic corporate manager behavior so that there will be no alignment of interests between shareholders and managers which ultimately will raises information asymmetry so that it has an impact on less qualified financial reporting via the internet. The results of this study contradict the research conducted by Andriyani and Mudjiyanti (2017) which states that the number of independent board of directors has a positive effect on IFR

4) Effect of Return on Assets on the Quality Internet Reporting Quality

Return on assets had no effect on internet quality financial reporting as indicated by the regression coefficient of 0.074 and a significance value of 0.795 so that $\mathrm{H} 4$ was rejected. ROA in this study is low which reflects the company's poor 
performance, causing the IFR quality to be low, namely the company limits the disclosure of financial and non-financial information contained in its website. The results of this study are in line with those conducted by Ezat and ElMashry (2008) which states that profitability has no influence on internet financial reporting

5) Effect of Leverage on the Quality Internet financial reporting

Leverage has an effect but not significant on internet quality financial reporting as indicated by a regression coefficient of -

\section{CONCLUSION}

1) Institutional ownership does not significantly influence on the quality of internet financial reporting

2) Frequency of meeting of the board of commissioners does not have a significant effect on the quality of internet financial reporting

\section{REFFERENCE}

Ale, L. (2014). Pengaruh Ukuran Perusahaan, Leverage, Kepemilikan Institusional dan Ukuran Dewan Komisaris Terhadap Pengungkapan Corporate Social Responsibility. Ejournal Universitas Atmajaya

Andriyani, R,.Mudjiyanti,R. 2017. "Pengaruh Tingkat Profitabilitas, Leverage, Jumlah Komisaris Independen dan Kepemilikan Institusional Terhadap
0.151 and a significance value of 0.139 so that $\mathrm{H} 5$ is rejected. The results of the analysis show that high leverage does not cause an increase in the quality of internet financial reporting but makes management difficult to predict the future sustainability of the company. The results of this analysis are in line with the research of Harsanti, Mulyani and Fahmi (2014) and Kusrinanti and Syafrudin (2014) which state that leverage does not affect the quality of internet financial reporting

3) Proportion of the board of commissioners does not have a significant effect on the quality of internet financial reporting

4) Return on assets has no significant effect on the quality of internet financial reporting

5) Leverage has no significant effect on the quality of internet financial reporting

Pengungkapan Internet Financial Reporting (IFR) di Bursa Efek Indonesia”. Kompartemen Vol.XV (1)

Ashbaugh, H., Johnstone, K. M., Warfield, T.D. (1999). "Corporate Reporting on the Internet", Accounting Horizons, 13(3): 241257

Boediono, G.S.B. 2005. "Kualitas Laba : Studi Pengaruh Mekanisme Corporate Governance Dan 
Dampak Manajemen Laba

Dengan Menggunakan Analisis

Jalur". Simposium Nasional Akuntansi VIII. Solo

Denis, D.K., Mcconnell, J.J. (2003). International

Corporate

Governance. Papers.ssrn.com

Ezat, El-Masry. (2008). "The Impact of Corporate Governance on the Timeliness of Internet financial reporting by Egyptian listed Company". Managerial Finance, Vol. 34 Iss: 12, pp. $848-867$

Ghozali, Imam \& Gedie E Siagian. 2012. Pengaruh Struktur Dan Aktivitas Good Corporate Governance Terhadap Luas Pengungkapan Informasi Strategis Secara Sukarela Pada Website Perusahaan Yang Terdaftar Dalam Bursa Efek Indonesia. E-Journal Universitas Diponegoro Vol. 01 No.02 Hal,1-11

Hardikasari, E., 2011. Pengaruh Penerapan Corporate Governance Terhadap Kinerja Keuangan Pada Industri Perbankan Yang Terdaftar Di Bursa Efek Indonesia (BEI) Tahun 2006 - 2008. eprint.undip.co.id

Hidayah, N., (2015). Pengaruh Investment Opportunity Set (IOS) dan Kepemilikan Manajerial Terhadap Nilai Perusahaan Pada Perusahaan Property dan Real Estate di Buersa Efek Indonesia. Jurnal Akuntansi Vol. XIX No. 03, September $2015: 420-432$

Kusrinanti,MA.,Syafrudin,M dan

Haryani. 2012. Pengaruh Corporate Governance Terhadap Ketepatan Waktu Corporate Internet Reporting Pada Perusahaan Yang Terdaftar di
Bursa Efek Indonesia. Simposium

Nasional Akuntansi XII

Pelembang

La Porta, R., Lopez de Silanes, F., Shleifer, A., Vishny, R.W. (1998). Law and Finance. The Journal of Political Economy, 106(6): 11131155

Lai, Syou-Ching., Lin, Cecilia., Lee, Hung-Chih., and $\mathrm{Wu}$, Frederick $\mathrm{H}$. 2009. "An Empirical Study of the Impact of Internet Financial Reporting on Stock Prices"

Peraturan Otoritas Jasa Keuangan Nomor 29/POJK.04/2016

Rahmadiani,H. Pengaruh Kinerja Keuangan Terhadap Tingkat pengungkapan Internet Financcial Reporting Dalam Website Perusahaan Pada Perusahaan Manufaktur Di Bursa Efek Indonesia. fe-akuntansi.unila.ac.id Spence, M. (1973). Job Market Signalling. Quarterly Journal of Economics. pp. 355-374

Utami, W.,(2015). Financial Performance and The Quality of Sustainability Disclosure Based On Global Reporting Initiative : Value Relevances Study in Indonesia Stock Exchange. Mediterranean Journal of Social Science. Vol 6 (5) S5 October www.internetworldstats.com

Yatim, Puan., Pamela Kent dan Peter Clarkson. (2006). Governance Structures, Ethnicity, dan Audit Fees of Malaysian Listed Firms. Business Paper School of Business. Bond University 